\title{
Ionic Liquid-Derived Carbon-Supported Metal Electrocatalysts as Anodes in Direct Borohydride-Peroxide Fuel Cells
}

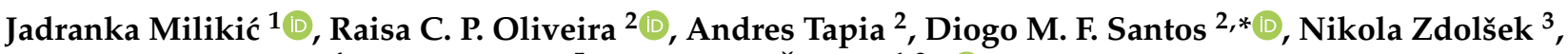 \\ Tatjana Trtić-Petrović ${ }^{4}$, Milan Vraneš ${ }^{5}$ and Biljana Šljukić ${ }^{1,2, * \mathbb{D}}$ \\ 1 Faculty of Physical Chemistry, University of Belgrade, Studentski trg 12-16, 11158 Belgrade, Serbia; \\ jadranka@ffh.bg.ac.rs \\ 2 CeFEMA, Instituto Superior Técnico, Universidade de Lisboa, 1049-001 Lisbon, Portugal; \\ raisa.oliveira@tecnico.ulisboa.pt (R.C.P.O.); andrest1705@hotmail.com (A.T.) \\ 3 Laboratory of Physical Chemistry, "Vinča" Institute of Nuclear Sciences-National Institute of the Republic of Serbia, \\ University of Belgrade, 11001 Belgrade, Serbia; zdolsek@vin.bg.ac.rs \\ 4 Laboratory of Physics, "Vinča" Institute of Nuclear Sciences-National Institute of the Republic of Serbia, \\ University of Belgrade, 11001 Belgrade, Serbia; ttrtic@vin.bg.ac.rs \\ 5 Department of Chemistry, Biochemistry and Environmental Protection, Faculty of Science, University of Novi Sad, \\ Trg Dositeja Obradovića 3, 21000 Novi Sad, Serbia; milan.vranes@dh.uns.ac.rs \\ * Correspondence: diogosantos@tecnico.ulisboa.pt (D.M.F.S.); biljka@ffh.bg.ac.rs (B.Š.); \\ Tel.: +351-21-841-77-65 (D.M.F.S.); +381-11-333-68-94 (B.Š.)
}

Citation: Milikić, J.; Oliveira, R.C.P.; Tapia, A.; Santos, D.M.F.; Zdolšek, N.; Trtić-Petrović, T.; Vraneš, M.; Šljukić, B. Ionic Liquid-Derived Carbon-Supported Metal Electrocatalysts as Anodes in Direct Borohydride-Peroxide Fuel Cells. Catalysts 2021, 11, 632. https:// doi.org/10.3390/catal11050632

Academic Editor: Carmelo Lo Vecchio

Received: 8 April 2021

Accepted: 11 May 2021

Published: 14 May 2021

Publisher's Note: MDPI stays neutral with regard to jurisdictional claims in published maps and institutional affiliations.

Copyright: (c) 2021 by the authors. Licensee MDPI, Basel, Switzerland. This article is an open access article distributed under the terms and conditions of the Creative Commons Attribution (CC BY) license (https:// creativecommons.org/licenses/by/ $4.0 /)$.

\begin{abstract}
Three different carbon-supported metal (gold, platinum, nickel) nanoparticle (M/c-IL) electrocatalysts are prepared by template-free carbonization of the corresponding ionic liquids, namely $[\mathrm{Hmim}]\left[\mathrm{AuCl}_{4}\right],[\mathrm{Hmim}]_{2}\left[\mathrm{PtCl}_{4}\right]$, and $\left[\mathrm{C}_{16} \mathrm{mim}_{2}\left[\mathrm{NiCl}_{4}\right]\right.$, as confirmed by $\mathrm{X}$-ray diffraction analysis, scanning electron microscopy coupled with energy-dispersive $\mathrm{X}$-ray spectroscopy and Raman spectroscopy. The electrochemical investigation of borohydride oxidation reaction (BOR) at the three electrocatalysts by cyclic voltammetry reveals different behavior for each material. $\mathrm{BOR}$ is found to be a first-order reaction at the three electrocatalysts, with an apparent activation energy of 10.6 and $13.8 \mathrm{~kJ} \mathrm{~mol}^{-1}$ for Pt/c-IL and Au/c-IL electrocatalysts, respectively. A number of exchanged electrons of 5.0, 2.4, and 2.0 is obtained for BOR at Pt/c-IL, Au/c-IL, and Ni/c-IL electrodes, respectively. Direct borohydride-peroxide fuel cell (DBPFC) tests done at temperatures in the $25-65{ }^{\circ} \mathrm{C}$ range show ca. four times higher power density when using a Pt/c-IL anode than with an $\mathrm{Au} / \mathrm{c}-\mathrm{IL}$ anode. Peak power densities of 40.6 and $120.5 \mathrm{~mW} \mathrm{~cm}^{-2}$ are achieved at 25 and $65^{\circ} \mathrm{C}$, respectively, for DBPFC with a Pt/c-IL anode electrocatalyst.
\end{abstract}

Keywords: platinum; gold; nickel; borohydride oxidation reaction; carbonized ionic liquids; direct borohydride-peroxide fuel cells

\section{Introduction}

Ionic liquids (ILs) are nowadays finding many applications, including as reaction solvents in different synthesis procedures, such as polymerization, esterification, or acidic hydrolysis [1,2]. They have various cation-anion combinations, a carbon-rich nature, low corrosivity, low volatility, tunable solubility, and very good thermal stability [3]. Thus, recent studies are focusing on the combination of excellent properties of carbon nanomaterials and their functionalization with ILs to create new sorbent materials, of high loading capacity, good durability, reliability, selectivity, and sensitivity [4,5]. For instance, the low-temperature synthesis of porous carbon material from pyrolysis of cellulose using 18 types of ILs as a reusable agent was reported by Huang et al. [6]. The synthesis of porous carbon nanomaterials by the direct carbonization of ILs has further advantages for a notably simpler procedure (compared to, for instance, traditionally used carbonization of polymers) [7], leading to carbons of unique features such as high nitrogen content. This fur- 
ther enables the use of these carbon materials as efficient electrocatalysts for energy-related applications [8].

The carbonization of an ionic liquid containing metal leads to the formation of carbonsupported metal nanoparticles. Thus, this work presents the carbonization of three different ILs: $\left[\mathrm{C}_{16} \mathrm{mim}_{2}\left[\mathrm{NiCl}_{4}\right],[\mathrm{Hmim}]\left[\mathrm{AuCl}_{4}\right]\right.$, and $[\mathrm{Hmim}]_{2}\left[\mathrm{PtCl}_{4}\right]$, and the first-time assessment of thus prepared carbon-supported metal nanoparticles, as electrocatalysts for the borohydride oxidation reaction (BOR).

BOR occurs at the anode side in a direct borohydride fuel cell (DBFC), where $8 \mathrm{e}^{-}$ could be exchanged during the electrochemical oxidation of each $\mathrm{BH}_{4}{ }^{-}$ion. Platinum $(\mathrm{Pt})$, gold $(\mathrm{Au})$, palladium $(\mathrm{Pd})$, and their alloys are the most examined noble metals for BOR [9]. Olu and coworkers have tested $\mathrm{Pt} / \mathrm{C}$ and $\mathrm{Pd} / \mathrm{C}$ electrocatalysts in $\mathrm{NaBH}_{4}$ solution, where the $\mathrm{Pd} / \mathrm{C}$ electrode showed comparable open circuit potential (OCP) value about $-26 \mathrm{mV}$ vs. RHE with Pt/C electrocatalysts during BOR [10]. Cyclic voltammograms (CVs) of Pt/C and $\mathrm{Pd} / \mathrm{C}$ electrocatalysts obtained in $10 \mathrm{mM} \mathrm{NaBH}_{4}$ solution were completely different; $\mathrm{Pt} / \mathrm{C}$ gave three high-intensity oxidation peaks, whereas the $\mathrm{Pd} / \mathrm{C}$ electrocatalyst gave a low- and a high-intensity oxidation peak. During BOR at nanoporous gold electrodes, ca. 4.26 electrons were exchanged [11]. Two gold nanorod-polyaniline (Au-PANI) composites were used as anodes in a DBPFC where Au-PANI anode with a very low Au amount gave a specific power density of $184 \mathrm{~W} \mathrm{~g}^{-1} \mathrm{Au}$ at $65^{\circ} \mathrm{C}$ [12]. Nickel (Ni), as a non-noble metal, (and its alloys), is a more attractive electrocatalyst for BOR. Among bulk Ni and Ni-rare earth alloy electrodes tested for BOR, the $\mathrm{Ni}_{0.95} \mathrm{Dy}_{0.05}$ electrode showed the best performance, as evidenced by the lowest apparent activation energy and the highest number of exchanged electrons during BOR [13]. By the same criteria, carbon-supported $\mathrm{Pt}_{0.75} \mathrm{Ni}_{0.25}$ nanoparticles exhibited superior electrocatalytic activity for $\mathrm{BH}_{4}{ }^{-}$oxidation compared to $\mathrm{Pt} / \mathrm{C}$ and $\mathrm{Pt}_{0.75} \mathrm{Co}_{0.25} / \mathrm{C}$ [14]. NiPt nanoparticles with core shell structures showed activity for BOR, with their activity being notably influenced by the synthesis procedure, so that electrocatalyst prepared with no anionic surfactant exhibited higher catalytic activity towards BOR [15].

Some reports showed that carbon-based materials are the best choice of support for low-temperature fuel cell metal nanoparticles electrocatalysts, because of excellent electrochemical and mechanical performances, such as good corrosion resistance and unique surface properties, large porosity, high electrical conductivity, and large specific surface area (even $700 \mathrm{~m}^{2} \mathrm{~g}^{-1}$ ) [8,16-18]. As mentioned, within this study, three carbonsupported metal nanoparticle materials were prepared by the carbonization of ILs and characterized by Raman spectroscopy, scanning electron microscopy coupled with energydispersive X-ray spectroscopy (SEM/EDS), and X-ray diffraction (XRD) analysis. A detailed electrochemical investigation of BOR at the carbonized ILs was done by cyclic voltammetry.

\section{Results}

\subsection{Characterization of $\mathrm{Ni} / \mathrm{c}-\mathrm{IL}$}

XRD pattern of Pt/c-IL (Figure 1A) shows peaks at ca. 40, 46.5, 67.8, 81.5, and $86^{\circ}$ corresponding to diffraction from (111), (200), (220), (311), and (222) planes of Fm $\overline{3} \mathrm{~m}$ space group. In the case of $\mathrm{Ni} / \mathrm{c}-\mathrm{IL}, \mathrm{Ni}$ and a negligible amount of $\mathrm{NiO}$ phases were identified by XRD (Figure 1B). Thus, the XRD pattern of Ni/c-IL composite shows three intensive phase peaks at $2 \theta$ of $44.1,51.9$, and $76.6^{\circ}$ corresponding to diffraction from (111), (200), and (220) planes of the $\mathrm{Ni}$, respectively, and several smaller intensive peaks of the $\mathrm{NiO}$ phase [19-21]. The presence of $\mathrm{NiO}$ is not unusual, since the precursor contained $\mathrm{Ni}$ in the form of $\mathrm{NiCl}_{2}$ that could be transformed into $\mathrm{NiO}$ during the carbonization process. Similar behavior was observed when using $\mathrm{FeCl}_{2}$ [22]. XRD pattern of Au/c-IL (Figure 1C) reveals five characteristic peaks at $2 \theta$ of $38.6,44.8,64.9,77.9$, and $82.1^{\circ}$, corresponding to the diffraction from (111), (200), (220), (311), and (222) planes of crystal facets of $\mathrm{Au}$, respectively $[12,23]$. There was no evidence of the formation of crystalline carbon, and the internal carbon in both samples can be assumed to be a contribution to the background. 

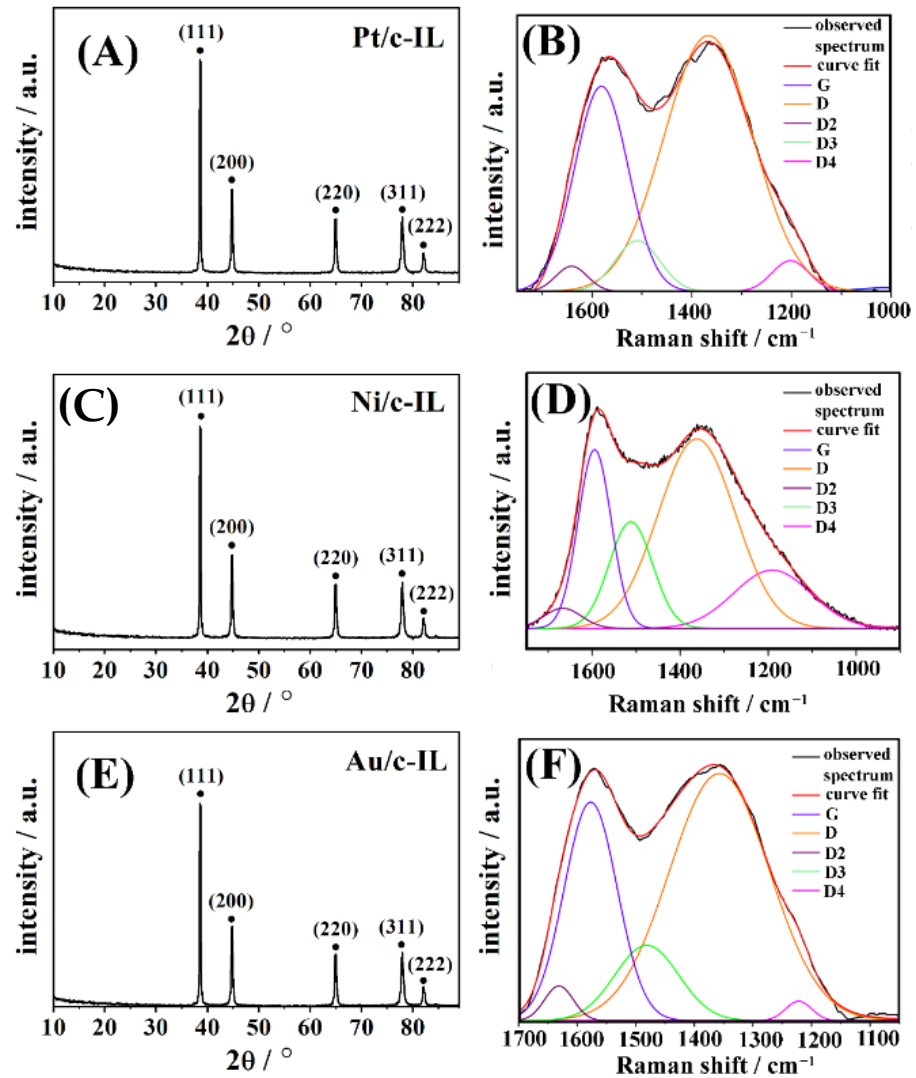

Figure 1. XRD patterns $(\mathbf{A}, \mathbf{C}, \mathbf{E})$ and deconvoluted Raman spectra $(\mathbf{B}, \mathbf{D}, \mathbf{F})$ of the three electrocatalysts.

Figure 1B,D,F illustrates the Raman spectra of Pt/c-IL, Ni/c-IL, and Au/c-IL, which along with $\mathrm{D}$ and $\mathrm{G}$ peaks, contain three additional bands associated with the $\mathrm{D}$ band: $\mathrm{D} 2$, $\mathrm{D} 3$, and D4 [24]. The $\mathrm{I}_{\mathrm{D}} / \mathrm{I}_{\mathrm{G}}$ ratios were calculated to be 2.5, 2.13, and 2.07 for Ni/c-IL, Au/c$\mathrm{IL}$, and $\mathrm{Pt} / \mathrm{c}-\mathrm{IL}$, respectively, indicating carbon structure with a number of defects [24]. $\mathrm{I}_{\mathrm{D} 3} / \mathrm{I}_{\mathrm{G}}$ ratio was the highest in the case of Ni/c-IL (0.8), followed by Au/c-IL (0.4) and the lowest in the case of Pt/c-IL (0.2). This result implies the low crystallinity of Ni/c-IL and $\mathrm{Au} / \mathrm{c}-\mathrm{IL}$ compared to Pt/c-IL [25].

SEM analysis (Figure S1, in Supplementary Information) revealed the uniform distribution of metals on carbon with islands of agglomerated metal nanoparticles.

\subsection{Borohydride Oxidation Study}

$\mathrm{CVs}$ of $\mathrm{Pt} / \mathrm{c}-\mathrm{IL}$ and $\mathrm{Au} / \mathrm{c}-\mathrm{IL}$ electrocatalysts in the absence of $\mathrm{BH}_{4}{ }^{-}$(Figure 2A,C, solid lines) show low current densities $\left(<0.5 \mathrm{~mA} \mathrm{~cm}{ }^{-2}\right)$, with small peaks that can be associated with the formation and reduction of gold and platinum oxides in alkaline media [26]. No other relevant redox processes were observed on those CVs. CV of Ni/cIL in the supporting electrolyte shows an anodic peak at $1.47 \mathrm{~V}$ and a cathodic peak at $1.37 \mathrm{~V}$, corresponding to the $\mathrm{Ni}^{3+} / \mathrm{Ni}^{2+}$ redox couple conversion in alkaline media (Figure 2B) [15,27]. The oxidation of metallic Ni in alkaline media is known to involve three main steps in the studied potential range [27]. The first step is the formation of the $\alpha-\mathrm{Ni}(\mathrm{OH})_{2}$ according to Equation (1) in the potential range $0 \leq \mathrm{E}_{\mathrm{RHE}} \leq 0.5 \mathrm{~V}$.

$$
\mathrm{Ni}^{0}+2 \mathrm{OH}^{-} \rightleftharpoons \alpha-\mathrm{Ni}(\mathrm{OH})_{2}+2 \mathrm{e}^{-}
$$

With increasing potential $\left(0.5 \leq \mathrm{E}_{\mathrm{RHE}} \leq 1.4 \mathrm{~V}\right)$, the $\alpha-\mathrm{Ni}(\mathrm{OH})_{2}$ hydroxide could convert into a less hydrated and more stable phase, $\beta-\mathrm{Ni}(\mathrm{OH})_{2}$ (Equation (2)). This $\beta$-phase can also be generated directly from $\mathrm{Ni}^{0}$.

$$
\alpha-\mathrm{Ni}(\mathrm{OH})_{2} \rightleftharpoons \beta-\mathrm{Ni}(\mathrm{OH})_{2}
$$



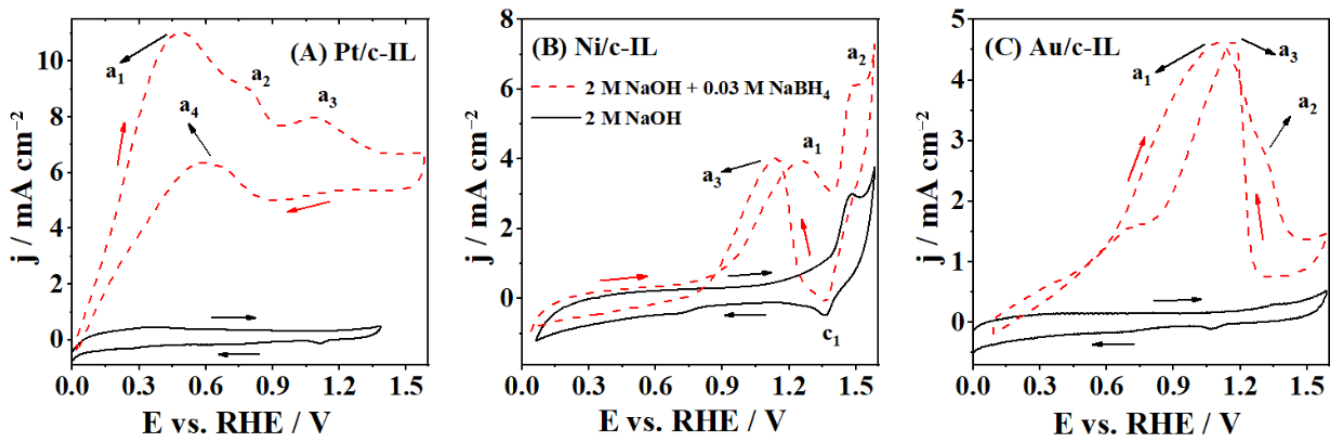

Figure 2. $\mathrm{CVs}$ of (A) Pt/c-IL, (B) Ni/c-IL and (C) Au/c-IL at $25{ }^{\circ} \mathrm{C}$ in $2 \mathrm{M} \mathrm{NaOH}$ supporting electrolyte (solid line) and in $2 \mathrm{M} \mathrm{NaOH}+0.03 \mathrm{M} \mathrm{NaBH}_{4}$ (dashed line).

Finally, for $\mathrm{E}_{\mathrm{RHE}}>1.4 \mathrm{~V}$, this $\beta$-hydroxide is oxidized in an oxy-hydroxide species, according to Equation (3). The formation of $\beta-\mathrm{NiOOH}$ is essential, since it is active for oxidative electrocatalysis, namely for methanol [28], ethanol [29], glycerol [30], and borohydride oxidation $[15,27,31,32]$.

$$
\beta-\mathrm{Ni}(\mathrm{OH})_{2}+\mathrm{OH}^{-} \rightleftharpoons \beta-\mathrm{NiOOH}+\mathrm{H}_{2} \mathrm{O}+\mathrm{e}^{-}
$$

Regarding the CVs in the presence of $\mathrm{BH}_{4}{ }^{-}$(Figure 2, dashed lines), different behaviors are observed for each electrocatalyst. $\mathrm{Pt} / \mathrm{c}$-IL shows two well-defined peaks in the direct scan at $0.48 \mathrm{~V}\left(\mathrm{j}_{\mathrm{a} 1}=11.1 \mathrm{~mA} \mathrm{~cm}^{-2}\right)$ and $1.09 \mathrm{~V}\left(\mathrm{j}_{\mathrm{a} 3}=8.0 \mathrm{~mA} \mathrm{~cm}^{-2}\right)$ and a shoulder at $0.79 \mathrm{~V}$ $\left(\mathrm{j}_{\mathrm{a} 2}=9.1 \mathrm{~mA} \mathrm{~cm}^{-2}\right)$ (Figure 2A). In the back scan, another oxidation peak is observed at $0.59 \mathrm{~V}\left(\mathrm{j}_{\mathrm{a} 4}=6.4 \mathrm{~mA} \mathrm{~cm}{ }^{-2}\right)$. The presence of those peaks evidences the occurrence of both BOR (Equation (4), peak $\mathrm{a}_{3}$ ) and its competitive reaction, $\mathrm{BH}_{4}{ }^{-}$hydrolysis (Equation (5)), and the subsequent oxidation of the hydrolysis products, $\mathrm{H}_{2}$ (peak $\mathrm{a}_{1}$ ) and $\mathrm{BH}_{3} \mathrm{OH}^{-}$ (Equations (6) and (7), peak $\mathrm{a}_{2}$ and $\mathrm{a}_{4}$ ) [33].

$$
\begin{gathered}
\mathrm{BH}_{4}{ }^{-}+8 \mathrm{OH}^{-} \rightleftharpoons \mathrm{BO}_{2}{ }^{-}+6 \mathrm{H}_{2} \mathrm{O}+8 \mathrm{e}^{-} \\
\mathrm{BH}_{4}{ }^{-}+\mathrm{H}_{2} \mathrm{O} \rightleftharpoons \mathrm{BH}_{3} \mathrm{OH}^{-}+\mathrm{H}_{2} \\
\mathrm{BH}_{3} \mathrm{OH}^{-}+6 \mathrm{OH}^{-} \rightleftharpoons \mathrm{B}(\mathrm{OH})_{4}{ }^{-}+3 \mathrm{H}_{2} \mathrm{O}+6 \mathrm{e}^{-} \\
\mathrm{BH}_{3} \mathrm{OH}^{-}+3 \mathrm{OH}^{-} \rightleftharpoons \mathrm{B}(\mathrm{OH})_{4}{ }^{-}+{ }^{3} /{ }_{2} \mathrm{H}_{2} \mathrm{O}+3 \mathrm{e}^{-}
\end{gathered}
$$

Regarding Ni/c-IL, three anodic peaks were observed in the $\mathrm{CV}$ performed in the presence of $\mathrm{BH}_{4}^{-}$(Figure 2B). Those processes appear in a zone of high overpotential, namely peak $\mathrm{a}_{1}$ at $1.26 \mathrm{~V}\left(\mathrm{j}_{\mathrm{a} 1}=3.9 \mathrm{~mA} \mathrm{~cm}^{-2}\right)$, peak $\mathrm{a}_{2}$ at $1.49 \mathrm{~V}\left(\mathrm{j}_{\mathrm{a} 2}=6.2 \mathrm{~mA} \mathrm{~cm}{ }^{-2}\right)$ and peak $\mathrm{a}_{3}$, in the back scan, at $1.14 \mathrm{~V}\left(\mathrm{j}_{\mathrm{a} 3}=4.1 \mathrm{~mA} \mathrm{~cm}^{-2}\right)$. Gas bubbles were observed on the electrode surface during all measurements, suggesting $\mathrm{H}_{2}$ generation by $\mathrm{BH}_{4}{ }^{-}$hydrolysis. Moreover, $\mathrm{a}_{1}$ most likely corresponds to $\mathrm{BH}_{3} \mathrm{OH}^{-}$oxidation and $\mathrm{a}_{2}$ corresponds to $\mathrm{BH}_{4}{ }^{-}$ oxidation proceeding in parallel with $\mathrm{NiOOH}$ generation [27]. The back scan peak $\left(\mathrm{a}_{3}\right)$ originates from the oxidation of $\mathrm{BH}_{3} \mathrm{OH}^{-}$ions (which remained adsorbed on the electrode surface during the anodic scan) after the reduction of nickel oxide, which leads to a reactivation of the catalyst surface. The mechanism of BOR at Ni-based electrodes is not completely known; thus, it was speculated that the BOR occurs only after the formation of $\mathrm{NiOOH}$, as given by Equation (8) [27,34].

$$
\mathrm{NiOOH}+\mathrm{NaBH}_{4} \rightleftharpoons \mathrm{Ni}(\mathrm{OH})_{2}+\text { oxidation products of } \mathrm{NaBH}_{4}
$$

However, simultaneous measurements of $\mathrm{H}_{2}$ and the electric current indicated that BOR- and $\mathrm{H}_{2}$-involving reactions occur in parallel at Ni-based electrodes, with metallic nickel being active for $\mathrm{BH}_{4}{ }^{-}$oxidation as shown by Oshchepkov et al. in a recent work [35]. The theoretical number of electrons exchanged (n) during BOR at the Ni electrode can be different depending on the mechanism pathway. If the stepwise pathway, originally proposed by Lee [36], is considered, BOR occurs according to Equations (9) and (10). Since this pathway involves four steps, a theoretical $\mathrm{n}$ of 4 could be reached. 


$$
\begin{gathered}
{\left[\mathrm{BH}_{\mathrm{x}}(\mathrm{OH})_{4-\mathrm{x}}\right]^{-} \rightleftharpoons\left(\mathrm{BH}_{\mathrm{x}-1}\right)\left[(\mathrm{OH})_{4-\mathrm{x}}\right]^{-}+\mathrm{H}} \\
{\left[\mathrm{BH}_{\mathrm{x}-1}(\mathrm{OH})_{4-\mathrm{x}}\right]^{-}+\mathrm{OH}^{-} \rightleftharpoons\left(\mathrm{BH}_{\mathrm{x}-1}\right)\left[(\mathrm{OH})_{5-\mathrm{x}}\right]^{-}+\mathrm{e}^{-} \quad(\mathrm{x}=1,2,3,4)}
\end{gathered}
$$

A second pathway considers the simultaneous occurrence of $\mathrm{BOR}$ and $\mathrm{BH}_{4}{ }^{-}$hydrolysis according to Equations (11) and (12) $[13,27,37]$. The number " $y$ " is highly dependent on the electrocatalyst surface and the potential and can change substantially according to the chemical, morphological and superficial properties of an Ni-based electrocatalyst.

$$
\begin{gathered}
{\left[\mathrm{BH}_{\mathrm{y}}(\mathrm{OH})_{4-\mathrm{y}}\right]^{-}+2 \mathrm{OH}^{-} \rightleftharpoons\left(\mathrm{BH}_{\mathrm{y}-1}\right)\left[(\mathrm{OH})_{5-\mathrm{y}}\right]^{-}+\mathrm{H}_{2} \mathrm{O}+2 \mathrm{e}^{-}} \\
{\left[\mathrm{BH}_{\mathrm{y}}(\mathrm{OH})_{4-\mathrm{y}}\right]^{-}+\mathrm{H}_{2} \mathrm{O} \rightleftharpoons\left(\mathrm{BH}_{\mathrm{y}-1}\right)\left[(\mathrm{OH})_{5-\mathrm{y}}\right]^{-}+\mathrm{H}_{2}}
\end{gathered}
$$

The appearance of an oxidation peak in the back scan of $\mathrm{Ni} / \mathrm{c}-\mathrm{IL} \mathrm{CV}$ in the presence of $\mathrm{BH}_{4}{ }^{-}$evidences a reactivation of the Ni electrode surface (Figure 2B). Oshchepkov et al. analyzed the effect of the metal oxidation grade on the activity of carbon-supported $\mathrm{Ni}$ based electrocatalysts for BOR [35], being observed that a partially oxidized Ni-based electrocatalyst achieved better performance than a highly oxidized one. In the case of $\mathrm{Ni} / \mathrm{c}-\mathrm{IL}$, it is believed that the catalytic activity of $\mathrm{Ni}(\mathrm{OH})_{2}$ is associated with $\mathrm{a}_{1}$ and $\mathrm{a}_{3}$, since they appear in a zone where this Ni-oxide species is already formed.

$\mathrm{Au} / \mathrm{c}$-IL exhibited the typical behavior of Au-based catalysts (Figure 2C), presenting three anodic peaks: $\mathrm{a}_{1}$ at $1.09 \mathrm{~V}\left(\mathrm{j}_{\mathrm{a} 1}=4.7 \mathrm{~mA} \mathrm{~cm}{ }^{-2}\right)$, an ill-defined shoulder $\left(\mathrm{a}_{2}\right)$ at $1.32 \mathrm{~V}$ $\left(\mathrm{j}_{\mathrm{a} 2}=2.8 \mathrm{~mA} \mathrm{~cm}^{-2}\right)$ in the direct scan, and $\mathrm{a}_{3}$ in the back scan at $1.18 \mathrm{~V}\left(\mathrm{j}_{\mathrm{a} 3}=4.7 \mathrm{~mA} \mathrm{~cm}{ }^{-2}\right)$ [38]. According to mechanistic studies [39], $\mathrm{a}_{1}$ is a combination of the oxidation of $\mathrm{BH}_{4}{ }^{-}$ hydrolysis-derivate species and low-potential $\mathrm{BH}_{4}{ }^{-}$direct oxidation, $\mathrm{a}_{2}$ is associated with an oxidation process involving $\mathrm{BH}_{2}(\mathrm{OH})_{2}{ }^{-}$or $\mathrm{BH}(\mathrm{OH})_{3}{ }^{-}$species. In $\mathrm{c}_{1}$ occurs the same process of $\mathrm{a}_{1}$, which proves that $\mathrm{Au}$ oxides are not active for $\mathrm{BOR}$, and after reactivation in the back scan (by a reduction reaction), the electrocatalyst becomes active again.

The irreversibility of the process was probed by observing the effect of the scan rate on the voltammograms of the three electrocatalysts, Figure 3. Pt/c-IL (Figure 3A) and Au/c-IL (Figure 3C) showed a shift of the peak to more positive potentials. Ni/c-IL (Figure 3B) did not demonstrate a considerable deviation of peak $a_{2}$ potential value, while $a_{1}$ seems to shift slightly to the left (Figure 3D). Furthermore, it was possible to observe an increase of the current density with an increasing scan rate for all electrocatalysts, especially for Pt/c-IL $(+173 \%)$ and $\mathrm{Ni} / \mathrm{c}-\mathrm{IL}\left(\mathrm{a}_{2},+135 \%\right)$, Figure 3E.

The effect of $\mathrm{BH}_{4}{ }^{-}$concentration was also analyzed for the three catalysts (Figure 4). An expected increase of the current density when increasing $\mathrm{BH}_{4}{ }^{-}$concentration for all catalysts is observed. From the slope of $\ln j$ vs. $\ln c$ regression (inset of Figure 4B), it was possible to calculate the order of the reaction $\beta$ with respect to $\mathrm{BH}_{4}{ }^{-}$for the three catalysts, Table 1. BOR on all c-IL-supported catalysts was found to be of the first order in respect to $\mathrm{BH}_{4}{ }^{-}$. Furthermore, the values obtained are close to those reported for similar catalysts, such as $\mathrm{Pt} / \mathrm{C}[40]$ and $\mathrm{Pt} / \mathrm{PPy}-\mathrm{C}$ (platinum nanoparticles supported on polypyrrole (PPy) + carbon composite) [41], or such as $\mathrm{Au} / \mathrm{C}$ [42] and bulk $\mathrm{Au}$ [43].

During all the experiments described above, $\mathrm{Ni}$ /c-IL exhibited unstable behavior. Namely, Ni/c-IL showed a critical decrease in BOR activity with continuous cycling, leading to the ill definition or even disappearance of BOR peak in the voltammograms. Oshchepkov et al. explained [35] that the decrease of BOR catalytic activity in the case of $\mathrm{Ni}$ electrodeposited on Vulcan $\mathrm{XC}-72 \mathrm{R}\left(\mathrm{Ni}_{\mathrm{ED}} / \mathrm{C}\right)$ catalyst was directly related to a decrease in the electrochemically active surface area (ECSA). When totally reduced, $\mathrm{Ni}_{\mathrm{ED}} / \mathrm{C}$ presented the maximum activity, when partially oxidized, an intermediate activity, and when totally oxidized, the lowest BOR activity. This oxidation resulted in a consequent decrease of the ECSA and a proportional reduction in $\mathrm{Ni}_{\mathrm{ED}} / \mathrm{C}$ catalytic activity for BOR. If the $\mathrm{Ni}$ is oxidized at very high potentials (as is the case of $\mathrm{Ni} / \mathrm{c}-\mathrm{IL}$ catalyst, Figure $4 \mathrm{~B}$ ), its reduction is extremely difficult or even impossible when in the presence of $\mathrm{BH}_{4}{ }^{-}$[35]. Thus, it was decided not to use $\mathrm{Ni}$ /c-IL catalyst in further studies, since $\mathrm{Ni} / \mathrm{c}-\mathrm{IL}$ is not stable enough to be used as an anode in a DBFC. 

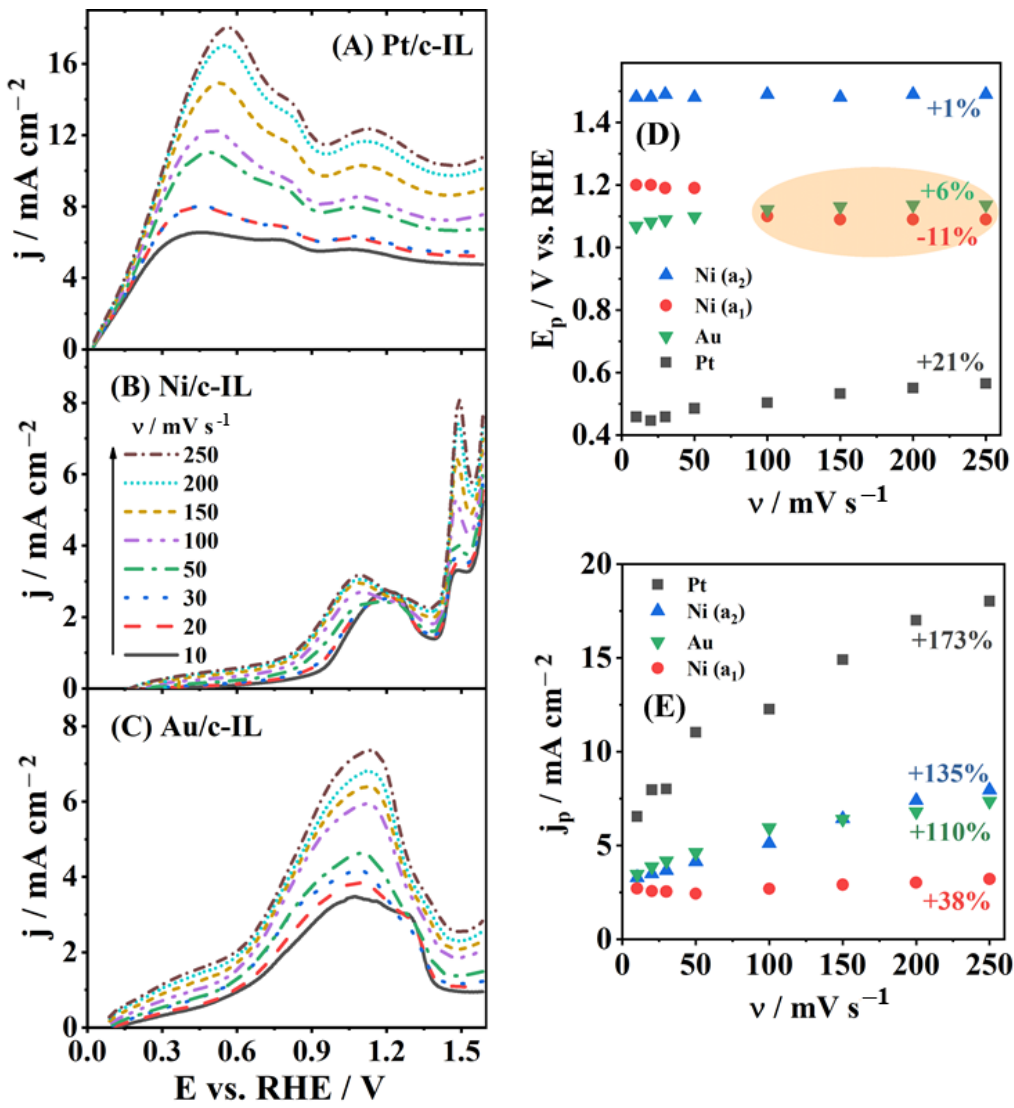

Figure 3. Linear sweep voltammograms of (A) Pt/c-IL, (B) Ni/c-IL, and (C) Au/c-IL at room temperature for different scan rates and the corresponding evolution of the (D) peak potential and (E) peak current density with the scan rate.
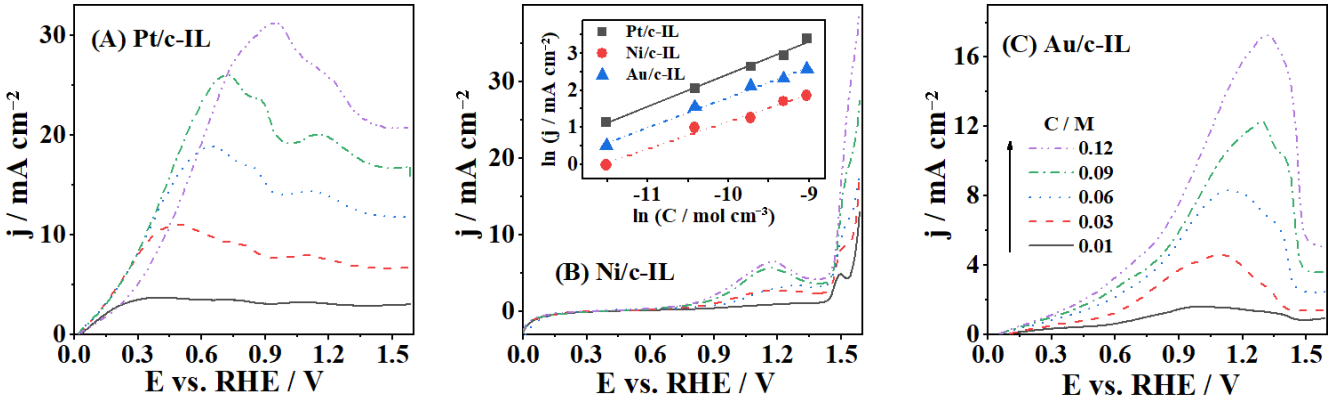

Figure 4. CVs of (A) Pt/c-IL, (B) Ni/c-IL, and (C) Au/c-IL in $\mathrm{NaBH}_{4}$ solution of different concentration $(0.01$ to $0.12 \mathrm{M})$ with the corresponding $\ln \mathrm{j}$ vs. ln $\mathrm{c}$ regressions inserted in (B).

The effect of an increasing temperature on BOR was also analyzed for Pt/c-IL and $\mathrm{Au} / \mathrm{c}-\mathrm{IL}$ catalysts (Figure 5). The enhancement of BOR kinetics at both Pt/c-IL and Au/c-IL by temperature increase was evidenced by the increase of the current density. This behavior allows the application of the Arrhenius equation to calculate the apparent activation energy $\mathrm{E}_{\mathrm{a}}$ app, Table $1 . \mathrm{BOR}$ at $\mathrm{Au} / \mathrm{c}-\mathrm{IL}$ presented a low $\mathrm{E}_{\mathrm{a}}{ }^{\text {app }}$ value $\left(13.8 \mathrm{~kJ} \mathrm{~mol}^{-1}\right)$, comparable to values reported for BOR at gold nanorod-polyaniline (Au-PANI) composites (12.6 and $14.1 \mathrm{~kJ} \mathrm{~mol}^{-1}$ ) [12] and notably lower than those obtained employing Au disk macroelectrodes (40-72 $\mathrm{kJ} \mathrm{mol}^{-1}$ ) [43]. Furthermore, a low $\mathrm{E}_{\mathrm{a}}$ app value of $10.6 \mathrm{~kJ} \mathrm{~mol}^{-1}$ was determined for BOR at $\mathrm{Pt} / \mathrm{c}$-IL, which is $6 \%$ lower than one of the lowest value found in the literature for Pt-based electrocatalysts [41] and ca. 38\% lower than the lowest one for $\mathrm{Pt} / \mathrm{C}$ [14], Table 1. 
Table 1. Order of reaction $\beta$ and apparent activation energy $E_{a}$ app values for Pt/c-IL, Ni/c-IL, and $\mathrm{Au} / \mathrm{c}-\mathrm{IL}$ catalysts.

\begin{tabular}{cccc}
\hline Catalyst & $\boldsymbol{\beta}$ & $\mathbf{E}_{\mathbf{a}}^{\mathbf{a p p}} \mathbf{/ k J ~ \mathbf { ~ m o l } ^ { - \mathbf { 1 } }}$ & Ref. \\
\hline $\mathrm{Pt} / \mathrm{c}-\mathrm{IL}$ & 0.88 & 10.6 & This work \\
$\mathrm{Ni} / \mathrm{c}-\mathrm{IL}$ & 0.74 & - & This work \\
$\mathrm{Au} / \mathrm{c}-\mathrm{IL}$ & 0.82 & 13.8 & This work \\
$\mathrm{Pt} / \mathrm{C}$ & 0.96 & 34 & {$[14]$} \\
$\mathrm{Pt} / \mathrm{C}$ & - & 16.3 & {$[40]$} \\
$\mathrm{Pt} / \mathrm{PPy}-\mathrm{C}_{5 \%}$ & 1.03 & 18 & {$[41]$} \\
$\mathrm{Pt} / \mathrm{PPy}-\mathrm{C}_{12} \%$ & 1.09 & 13 & {$[41]$} \\
$\mathrm{Pt} / \mathrm{PPy}-\mathrm{C}_{20} \%$ & 1.17 & 15 & {$[41]$} \\
$\mathrm{Pt} / \mathrm{PPy}-\mathrm{C}_{35 \%}$ & 0.85 & 10 & {$[41]$} \\
$\mathrm{Pt} / \mathrm{mpg}-\mathrm{C}_{3} \mathrm{~N}_{4}$ & 0.65 & 26 & {$[44]$} \\
$\mathrm{Au}(\mathrm{bulk})$ & {$[0.82-1.25]$} & 44 & {$[43]$} \\
$\mathrm{Au} / \mathrm{C}$ & {$[0.8-1.00]$} & - & {$[42]$} \\
\hline
\end{tabular}
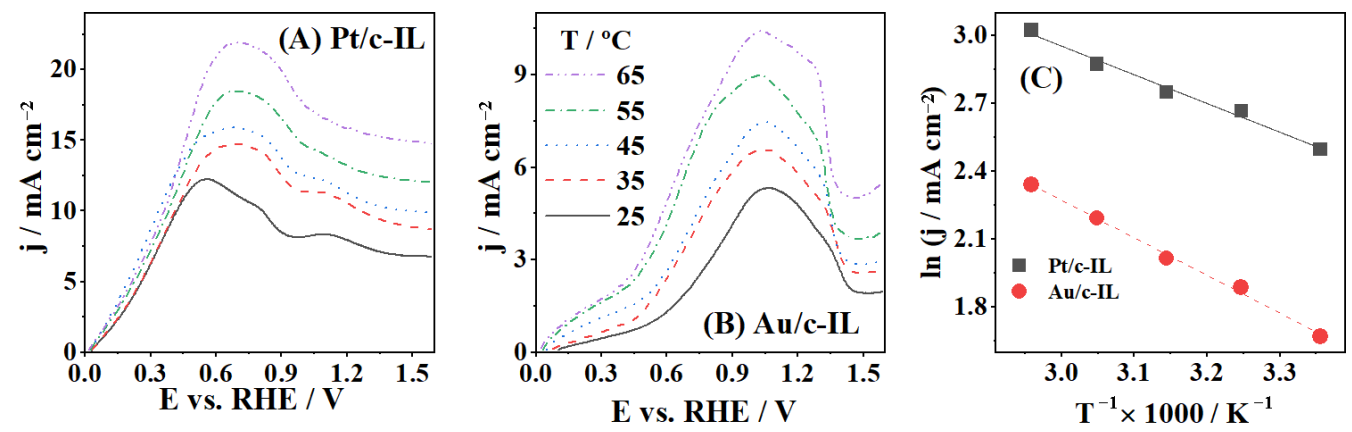

Figure 5. CVs of (A) Pt/c-IL and (B) Au/c-IL in $\mathrm{NaBH}_{4}$ solution of different temperatures (25 to $65^{\circ} \mathrm{C}$ ) and $(\mathrm{C})$ the corresponding $\ln \mathrm{j}$ vs. $1 / \mathrm{T}$ regressions.

To get further insight into the reaction mechanism, the number of exchanged electrons during BOR was calculated from rotating disk electrode (RDE) measurements (Figure 6) by employing the Koutecky-Levich (KL) equation [14]. The $\mathrm{j}^{-1}$ vs. $\omega^{-1 / 2}$ regressions shown in the inset of Figure 6B reveal good fitting (linearity) of the experimental points. An $n$ of 5.0 and 2.4 was calculated for BOR at Pt/c-IL and Au/c-IL, respectively. It should be mentioned that the number of electrons exchanged during BOR at commercial $\mathrm{Pt} / \mathrm{C}$ was found to be similar (5.2) (Figure 6C).

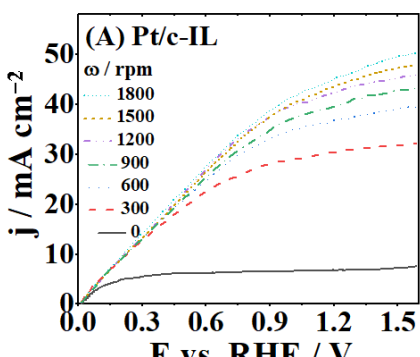

E vs. RHE / V
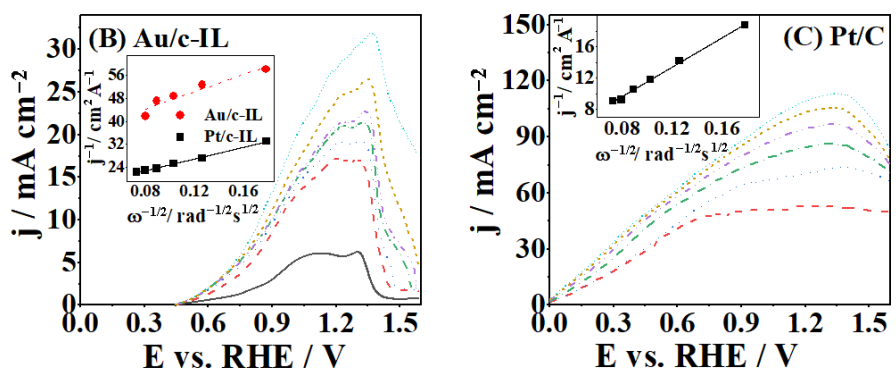

Figure 6. RDE studies for (A) Pt/c-IL and (B) Au/c-IL with the corresponding Koutecky-Levich plots in the inset, and for $(\mathrm{C})$ commercial $\mathrm{Pt} / \mathrm{C}$ with the corresponding Koutecky-Levich plot in the inset.

As it was not possible to run RDE measurements with Ni/c-IL catalysts, the number of exchanged electrons was evaluated from the above-described current density vs. square root of scan rate study [14]. Thus, it was calculated that 2 electrons were exchanged during BOR at $\mathrm{Ni} / \mathrm{c}-\mathrm{IL}$, with this value being comparable to those reported for similar $\mathrm{Ni}$ samples [45]. 
The calculated $\mathrm{n}$ values suggest greater tendency for an indirect $\mathrm{BH}_{4}{ }^{-}$oxidation (according to Equations (5)-(7)), with an $\mathrm{n}<8$, or even a mixed direct (Equation (4)) and indirect oxidation of $\mathrm{BH}_{4}{ }^{-}$at three studied electrocatalysts. The BOR mechanism at Pt-, $\mathrm{Ni}-$, and Au-based electrodes is highly dependent on the electrocatalyst surface properties. The adsorption/desorption of the reduced/oxidized species determines the way in which BOR will occur.

\subsection{Fuel Cell Tests}

Figure 7 presents the polarization curves of DBPFC with Au/c-IL (Figure 7A) and $\mathrm{Pt} / \mathrm{c}$-IL anode (Figure 7B) at different temperatures with the corresponding power density curves. Open circuit voltage (OCV) was found to be ca. $1.6 \mathrm{~V}$ for DBPFC, with both Au/c-IL and $\mathrm{Pt} / \mathrm{c}$-IL anodes at all temperatures (Table 2). OCV value is lower than the theoretical value for DBPFCs with acidic catholyte due to the mixed overpotentials created by $\mathrm{BH}_{4}{ }^{-}$ hydrolysis and $\mathrm{H}_{2} \mathrm{O}_{2}$ decomposition species, i.e., the generation of $\mathrm{H}_{2}$ on the anode and the generation of $\mathrm{O}_{2}$ on the cathode side. Similarly, OCV values lower than the expected theoretical value were observed with commercial $\mathrm{Pt} / \mathrm{C}$ (Table 2), as well as in a previous work involving platinum polypyrrole-carbon (Pt/PPy-C) composites as anodes in DBPFC [41].

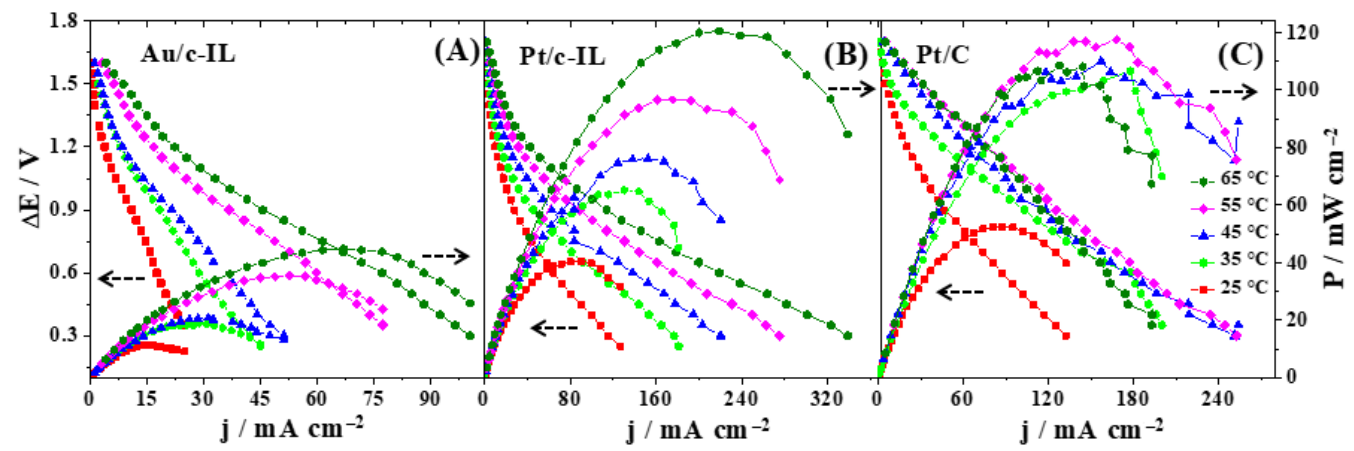

Figure 7. Cell polarization and specific power density curves of DBPFCs using (A) Au/c-IL, (B) Pt/c$\mathrm{IL}$, and $(\mathrm{C})$ commercial $\mathrm{Pt} / \mathrm{C}$ as anode catalyst at temperatures ranging from 25 to $65^{\circ} \mathrm{C}$.

The values of the peak power density, $\mathrm{P}_{\mathrm{p}}$, of DBPFC with both $\mathrm{Au} / \mathrm{c}$-IL and Pt/c-IL anode showed the same increasing trend with increasing temperatures, Table 2. Thus, DBPFC with Au/c-IL anode reached $P_{p}$ of $11.1 \mathrm{~mW} \mathrm{~cm}^{-2}$ and $43.5 \mathrm{~mW} \mathrm{~cm}^{-2}$ at 25 and $65^{\circ} \mathrm{C}$, respectively. $\mathrm{P}_{\mathrm{p}}$ of 40.6 and $120.5 \mathrm{~mW} \mathrm{~cm}^{-2}$ was reached with Pt/c-IL anode at 25 and $65^{\circ} \mathrm{C}$, respectively. This behavior could be a consequence of enhanced electron transfer kinetics, as well as decreased solution viscosity, increased species diffusion coefficient, and decreased ohmic losses. Electrochemical impedance spectroscopy measurements carried out in a previous work involving gold-rare earth alloys as DBPFC anodes at 25 and $45{ }^{\circ} \mathrm{C}$ showed a $61 \%$ decrease of the charge transfer resistance and consequent enhancement of BOR kinetics at $45^{\circ} \mathrm{C}$ [46]. It should be further noted that Pt/c-IL gave notably (three to four times) higher $\mathrm{P}_{\mathrm{p}}$ values than $\mathrm{Au} / \mathrm{c}-\mathrm{IL}$, at all temperatures.

DBPFC with commercial $\mathrm{Pt} / \mathrm{C}$ as anode electrocatalyst gave a peak power density of $52.4 \mathrm{~mW} \mathrm{~cm}^{-2}$ at $25^{\circ} \mathrm{C}$ (Figure 7C), i.e., higher than DBFPC with Pt/c-IL. This might be due to a better dispersion of the Pt nanoparticles in the case of the commercial electrocatalyst. As mentioned, some islands of agglomerated Pt nanoparticles have been observed in the case of $\mathrm{Pt} / \mathrm{c}$-IL. Moreover, a significant increase in peak power density of DBPFC with $\mathrm{Pt} / \mathrm{C}$ anode could be observed when increasing the temperature to $35^{\circ} \mathrm{C}$. However, further increasing above $45^{\circ} \mathrm{C}$ caused pronounced $\mathrm{BH}_{4}{ }^{-}$hydrolysis, as evidenced by vigorous bubbling at the anode side. This resulted in a decrease in peak power density when increasing the temperature from 55 to $65^{\circ} \mathrm{C}$. Thus, the peak power density of a DBPFC with commercial $\mathrm{Pt} / \mathrm{C}$ on the anode side reached a maximum value of $108.1 \mathrm{~mW} \mathrm{~cm}^{-2}$, i.e., lower than the DBPFC with herein prepared Pt/c-IL. 
Table 2. Parameters of DBPFC operating herein tested Au/c-IL and Pt/c-IL as anode electrocatalysts and comparison with similar literature reports.

\begin{tabular}{|c|c|c|c|c|c|}
\hline Electrode & $\mathrm{T} /{ }^{\circ} \mathrm{C}$ & $P_{p} / m_{W} \mathrm{~cm}^{-2}$ & $\mathrm{j}_{\mathrm{p}} / \mathrm{mA} \mathrm{cm}^{-2}$ & $\mathrm{OCV} / \mathrm{V}$ & Ref \\
\hline \multirow{5}{*}{$\mathrm{Au} / \mathrm{c}-\mathrm{IL}$} & 25 & 11.1 & 15.5 & 1.60 & This work \\
\hline & 35 & 18.4 & 28.5 & 1.50 & This work \\
\hline & 45 & 20.2 & 30.1 & 1.60 & This work \\
\hline & 55 & 34.2 & 52.6 & 1.60 & This work \\
\hline & 65 & 43.5 & 66.9 & 1.60 & This work \\
\hline \multirow{5}{*}{$\mathrm{Pt} / \mathrm{c}-\mathrm{IL}$} & 25 & 40.6 & 83.8 & 1.50 & This work \\
\hline & 35 & 65.2 & 131 & 1.60 & This work \\
\hline & 45 & 76.2 & 145 & 1.60 & This work \\
\hline & 55 & 96.6 & 177 & 1.60 & This work \\
\hline & 65 & 120 & 219 & 1.60 & This work \\
\hline \multirow{5}{*}{$\mathrm{Pt} / \mathrm{C}^{*}$} & 25 & 52.4 & 87.4 & 1.70 & This work \\
\hline & 35 & 100.2 & 143.2 & 1.70 & This work \\
\hline & 45 & 110.0 & 157.2 & 1.70 & This work \\
\hline & 55 & 117.2 & 167.9 & 1.70 & This work \\
\hline & 65 & 108.1 & 144.2 & 1.70 & This work \\
\hline $\mathrm{Pt} / \mathrm{C}$ & 25 & 34.1 & 50.0 & 1.74 & [47] \\
\hline $\mathrm{Pt} / \mathrm{G}^{* *}$ & 25 & 41.8 & 60.0 & 1.76 & [47] \\
\hline $\mathrm{Pt} / \mathrm{XC}-72 \mathrm{R}$ & 25 & 34.1 & 78.0 & 1.70 & {$[48]$} \\
\hline $\mathrm{Pt} / \mathrm{PPy}$ & 25 & 27.0 & 42.0 & 2.07 & [49] \\
\hline $\mathrm{Au} / \mathrm{C}$ & 20 & 28.2 & 60.0 & 1.90 & [50] \\
\hline $\mathrm{Au} / \mathrm{C}$ & 40 & 65.0 & 180.0 & 1.00 & [51] \\
\hline
\end{tabular}

* Commercial Pt/C electrocatalyst; ** Pt/G-graphene-supported Pt nanoparticles.

Graphene-supported Pt nanoparticles (Pt/G) and Vulcan XC-72R-supported Pt $(\mathrm{Pt} / \mathrm{C})$ nanoparticles were also employed as anodes in DBPFC at $25^{\circ} \mathrm{C}$ [47]. $\mathrm{P}_{\mathrm{p}}$ values of 34.1 and $41.8 \mathrm{~mW} \mathrm{~cm}{ }^{-2}$ were obtained with $\mathrm{Pt} / \mathrm{C}$ and $\mathrm{Pt} / \mathrm{G}$ anodes, respectively, which are lower/comparable with that of the herein tested Pt/c-IL anode [47]. DBPFC with $\mathrm{Pt}$ deposited on the nanoporous carbon showed somewhat better results at $25^{\circ} \mathrm{C}$, reaching $\mathrm{P}_{\mathrm{p}}$ of $54 \mathrm{~mW} \mathrm{~cm}^{-2}$ [48]. DBPFC with Pt on bulk polypyrrole film (Pt/PPy) reached a lower peak power density of $27 \mathrm{~mW} \mathrm{~cm}^{-2}$, with a corresponding current density of $42 \mathrm{~mA} \mathrm{~cm}^{-2}$ at room temperature [49].

The maximum power density of $28.2 \mathrm{~mW} \mathrm{~cm}^{-2}$ was obtained for DBPFC, with the carbon-supported Au-based electrocatalysts $(\mathrm{Au} / \mathrm{C})$ at $20^{\circ} \mathrm{C}$ [50]. Herein, an obtained $\mathrm{P}_{\mathrm{p}}$ value $11.1 \mathrm{~mW} \mathrm{~cm}{ }^{-2}$ for DBPFC with $\mathrm{Au} / \mathrm{c}$-IL at $25^{\circ} \mathrm{C}$ could be caused by the agglomeration of Au nanoparticles or enhanced $\mathrm{BH}_{4}{ }^{-}$hydrolysis at high concentration of $\mathrm{BH}_{4}{ }^{-}$ solution in DBFC/DBPFC and at high temperature [51].

\section{Materials and Methods}

\subsection{Preparation and Characterization of the (IL-c)-Supported Electrocatalysts}

Ionic liquids were prepared without solvent, by mixing and melting appropriate amounts of metal chloride and ionic liquids with chloride anion (1-hexyl-3-methylimidazolium chloride and 1-hexadecyl-3-methylimidazolium chloride) (Scheme 1) at a temperature of $85^{\circ} \mathrm{C}$, according to the reactions described in Equations (13)-(15).

$$
\begin{aligned}
2[\mathrm{Hmim}] \mathrm{Cl}+\mathrm{PtCl}_{2} & \rightarrow[\mathrm{Hmim}]_{2}\left[\mathrm{PtCl}_{4}\right] \\
2\left[\mathrm{C}_{16} \mathrm{mim}\right] \mathrm{Cl}+\mathrm{NiCl}_{2} & \rightarrow\left[\mathrm{C}_{16} \mathrm{mim}_{2}\left[\mathrm{NiCl}_{4}\right]\right. \\
{[\mathrm{Hmim}] \mathrm{Cl}+\mathrm{AuCl}_{3} } & \rightarrow[\mathrm{Hmim}]\left[\mathrm{AuCl}_{4}\right]
\end{aligned}
$$




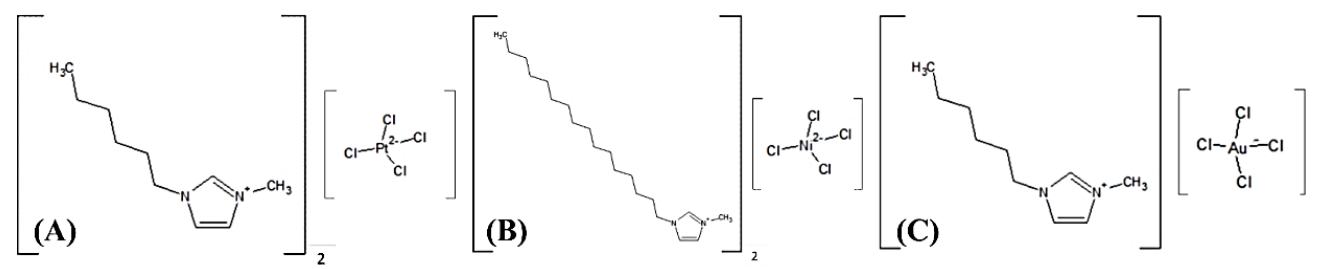

Scheme 1. Structure of $(\mathbf{A})\left[\mathrm{Hmim}_{2}\left[\mathrm{PtCl}_{4}\right],(\mathbf{B})\left[\mathrm{C}_{16} \mathrm{mim}\right]_{2}\left[\mathrm{NiCl}_{4}\right]\right.$, and $(\mathbf{C})[\mathrm{Hmim}]\left[\mathrm{AuCl}_{4}\right]$ ionic liquids.

Materials were prepared by the carbonization of $[\mathrm{Hmim}]_{2}\left[\mathrm{PtCl}_{4}\right],\left[\mathrm{C}_{16} \mathrm{mim}_{2}\left[\mathrm{NiCl}_{4}\right]\right.$, and $[\mathrm{Hmim}]\left[\mathrm{AuCl}_{4}\right]$ ionic liquids under $\mathrm{N}_{2}$ atmosphere $\left(\mathrm{N}_{2}\right.$ flow rate of $\left.35 \mathrm{~mL} \mathrm{~min}{ }^{-1}\right)$, in two steps. In the first step, ionic liquids were heated up to $400{ }^{\circ} \mathrm{C}$ and maintained at this temperature for $1 \mathrm{~h}$. In the second step, the materials were heated up to $800{ }^{\circ} \mathrm{C}$ for another hour. In both steps, the heating rate was $10^{\circ} \mathrm{C} \mathrm{min}^{-1}$. After the treatment at $800{ }^{\circ} \mathrm{C}$, the materials were left to cool to ambient temperature and denoted as $\mathrm{Pt} / \mathrm{c}$-IL, Ni/c-IL, and $\mathrm{Au} / \mathrm{c}-\mathrm{IL}$.

X-ray diffraction data were collected on a Philips PW 1050 (Philips, The Netherlands) diffractometer with $\mathrm{Cu}-\mathrm{K} \alpha_{1,2}$ radiation (Ni filter) at room temperature. Measurements were done in the $2 \theta$ range of $10-90^{\circ}$ with a scanning step width of $0.05^{\circ}$ and $3 \mathrm{~s}$ time per step. Raman spectra were collected on an Advantage 532 Raman spectrometer (DeltaNu Inc., Laramie, WY, USA), with YAG lesser operating at $532 \mathrm{~nm}$. Deconvolution of the spectra was performed using Gaussian fitting. Scanning electron microscope Phenom ${ }^{\mathrm{TM}}$ ProX Desktop SEM (ThermoFisher Scientific ${ }^{\mathrm{TM}}$, Waltham, MA, USA) with integrated energydispersive X-ray spectroscopy (EDS) detector was used to examine the surface morphology and composition.

\section{2. $\mathrm{NaBH}_{4}$ Oxidation Studies}

The catalytic inks were prepared by ultrasonically dispersing $5 \mathrm{mg}$ of the corresponding electrocatalyst and $0.6 \mathrm{mg}$ of Vulcan carbon in $125 \mu \mathrm{L}$ of a $2 \%$ polyvinylidene difluoride solution in N-methyl-2-pyrrolidone. The electrodes were prepared by depositing $10 \mu \mathrm{L}$ of the catalytic ink onto a glassy carbon tip and left to dry at $80{ }^{\circ} \mathrm{C}$ overnight. This procedure was done immediately after the ultrasonic step, to ensure the good dispersion of the electrocatalyst.

Electrochemical measurements were performed using Ivium V01107 Potentiostat/Galvanostat (Ivium Technologies B.V., Eindhoven, The Netherlands) in a one-compartment cell. A saturated calomel electrode (SCE, Metrohm, Herisau, Switzerland) and a graphite rod served as reference and counter electrode, respectively. All potentials within this paper were converted to the reversible hydrogen electrode (RHE) scale. Electrochemical measurements were done in $2 \mathrm{M} \mathrm{NaOH}$ (EKA, 98 wt.\%) solution, with or without $0.03 \mathrm{M} \mathrm{NaBH}_{4}(98$ wt.\%, Scharlau), except for the experiments on the effect of $\mathrm{NaBH}_{4}$ concentration. Cyclic voltammetry measurements were run in the $-0.01-1.6 \mathrm{~V}$ potential window, at scan rates ranging from 5 to $250 \mathrm{mV} \mathrm{s}^{-1}\left(25^{\circ} \mathrm{C}\right)$. Additionally, $\mathrm{CVs}$ were recorded at $50 \mathrm{mV} \mathrm{s}^{-1}$ in the $25-65{ }^{\circ} \mathrm{C}$ temperature range to verify the effect of temperature on the kinetics of the oxidation process. RDE experiments were done by running linear scan voltammetry experiments at $10 \mathrm{mV} \mathrm{s}^{-1}$ and rotation rates ranging from 0 to $1800 \mathrm{rpm}$. RDE experiments were also done with a commercial Pt/C (46.4 wt.\% Pt, Tanaka, Japan) electrocatalyst for comparison purposes. Finally, voltammetric experiments in $2 \mathrm{M} \mathrm{NaOH}$ solutions containing different concentrations of $\mathrm{NaBH}_{4}(0.01,0.03,0.06,0.09$ and $0.12 \mathrm{M})$ were run at $50 \mathrm{mV} \mathrm{s}{ }^{-1}\left(25^{\circ} \mathrm{C}\right)$.

\subsection{Fuel Cell Test}

The DBPFC tests were done by employing Pt/c-IL or Au/c-IL, as well as commercial $\mathrm{Pt} / \mathrm{C}$, as anode electrocatalyst and a Pt mesh (Johnson Matthey, $\mathrm{A}=50 \mathrm{~cm}^{2}$, London, England) as the cathode (to ensure that the cathodic reaction is not limiting the DBPFC performance). A Nafion N117 cation-exchange membrane (DuPont, Wilmington, DE, USA) was used as a separator. Moreover, a $1 \mathrm{M} \mathrm{NaBH}_{4}$ in $4 \mathrm{M} \mathrm{NaOH}$ solution was used as the 
anolyte, while a $5 \mathrm{M} \mathrm{H}_{2} \mathrm{O}_{2}$ (30 vol.\%, Carlo Erba, Barcelona, Spain) in $1.5 \mathrm{M} \mathrm{HCl}$ (37 wt.\%, Sigma Aldrich, Missouri, MO, USA) solution was used as the catholyte. The polarization and power density curves were recorded for the DBPFCs, employing different anode electrocatalysts in the $25-65^{\circ} \mathrm{C}$ temperature range.

\section{Conclusions}

Finally, $\left[\mathrm{C}_{16} \mathrm{mim}_{2}\left[\mathrm{NiCl}_{4}\right],[\mathrm{Hmim}]\left[\mathrm{AuCl}_{4}\right]\right.$, and $\left[\mathrm{Hmim}_{2}\left[\mathrm{PtCl}_{4}\right]\right.$ ionic liquids were successfully carbonized to produce carbon-supported metal nanoparticle electrocatalysts, as confirmed by XRD, Raman spectroscopy, and SEM/EDS analysis. Thus, prepared materials were systematically examined for BOR in highly alkaline media. Pt/c-IL, Ni/c-IL, and $\mathrm{Au} / \mathrm{c}-\mathrm{IL}$ electrocatalysts showed completely different behaviors in the presence of $\mathrm{BH}_{4}{ }^{-}$. Pt/c-IL gave the highest BOR current densities with two well-defined oxidation peaks and a shoulder (close to the first peak) on the direct scan. Reaction order was calculated to be close to 1 for all three electrocatalysts, with low apparent activation energy determined for BOR at Pt/c-IL and Au/c-IL. Number of electron transferred during BOR decreased in the order Pt/c-IL (5.0) > Au/c-IL (2.4) > Ni/c-IL (2.0). Moreover, Ni/c-IL showed unstable activity for BOR with time. DBPFCs' test run at $65^{\circ} \mathrm{C}$ showed peak power density of $43.5 \mathrm{~mW} \mathrm{~cm}^{-2}$ for Au/c-IL anode and of $120.5 \mathrm{~mW} \mathrm{~cm}^{-2}$ for Pt/c-IL anode, indicating $\mathrm{Pt} / \mathrm{c}-\mathrm{IL}$ as the best choice for the anode electrocatalyst leading to the highest DBPFC performance.

Supplementary Materials: The following are available online at https:/ /www.mdpi.com/article/10 $.3390 /$ catal11050632/s1, Figure S1. SEM/EDS analysis of the three studied electrocatalysts.

Author Contributions: Conceptualization, N.Z. and B.Š.; formal analysis, J.M., R.C.P.O., A.T. and N.Z.; investigation, J.M., A.T., M.V. and N.Z.; writing-original draft preparation, J.M., R.C.P.O.; writing-review and editing, D.M.F.S., T.T.-P. and B.Š.; visualization, J.M., R.C.P.O. and D.M.F.S.; supervision, D.M.F.S., T.T.-P. and B.S. All authors have read and agreed to the published version of the manuscript.

Funding: This research was funded by the Ministry of Education, Science and Technological Development of the Republic of Serbia, grant numbers 451-03-9/2021-14/200146 and 451-03-68/202014/200017, as well as by the Portuguese Foundation for Science and Technology (FCT, Portugal) for the PhD scholarship SFRH/BD/137470/2018 (R.C.P.O.), for the contract IST-ID/156/2018 (B.Š.), and a research contract in the scope of programmatic funding UIDP/04540/2020 (D.M.F.S.).

Data Availability Statement: The data presented in this study are available on request from the corresponding author.

Conflicts of Interest: The authors declare no conflict of interest. The funders had no role in the design of the study; in the collection, analyses, or interpretation of data; in the writing of the manuscript, or in the decision to publish the results.

\section{References}

1. Zhang, Z.; Song, J.; Han, B. Catalytic Transformation of lignocellulose into chemicals and fuel products in ionic liquids. Chem. Rev. 2017, 117, 6834-6880. [CrossRef]

2. Singh, S.K.; Savoy, A.W. Ionic liquids synthesis and applications: An overview. J. Mol. Liq. 2020, 297, 112038. [CrossRef]

3. Welton, T. Room-temperature ionic liquids: Solvents for synthesis and catalysis. Chem. Rev. 1999, 99, 2071-2083. [CrossRef] [PubMed]

4. Jon, C.S.; Meng, L.Y.; Li, D. Recent review on carbon nanomaterials functionalized with ionic liquids in sample pretreatment application. Trends Anal. Chem. 2019, 120, 115641. [CrossRef]

5. Mugadza, K.; Ndungu, P.G.; Stark, A.; Nyamori, V.O. Ionic liquids and cellulose: Innovative feedstock for synthesis of carbon nanostructured material. Mater. Chem. Phys. 2019, 234, 201-209. [CrossRef]

6. Huang, X.; Yamasaki, K.; Kudo, S.; Sperry, J.; Hayashi, J.-i. Influence of ionic liquid type on porous carbon formation during the ionothermal pyrolysis of cellulose. J. Anal. Appl. Pyrolysis 2020, 145, 104728. [CrossRef]

7. Zhang, S.; Dokko, K.; Watanabe, M. Carbon materialization of ionic liquids: From solvents to materials. Mater. Horiz. 2015, 2, 168-197. [CrossRef] 
8. Zdolšek, N.; Rocha, R.P.; Krstić, J.; Trtić-Petrović, T.; Šljukić, B.; Figueiredo, J.L.; Vujković, M.J. Electrochemical investigation of ionic liquid-derived porous carbon materials for supercapacitors: Pseudocapacitance versus electrical double layer. Electrochim. Acta 2019, 298, 541-551. [CrossRef]

9. Šljukić, B.; Santos, D.M.F. Direct borohydride fuel cells. In Direct Liquid Fuel Cells: Fundamentals, Advances and Future, 1st ed.; Akay, R.G., Yurtcan, A.B., Eds.; Academic Press: San Diego, CA, USA, 2020; Volume Chapter 10, pp. $203-232$.

10. Olu, P.Y.; Deschamps, F.; Caldarella, G.; Chatenet, M.; Job, N. Investigation of platinum and palladium as potential anodic catalysts for direct borohydride and ammonia borane fuel cells. J. Power Sources 2015, 297, 492-503. [CrossRef]

11. Nagle, L.C.; Rohan, J.F. Nanoporous gold anode catalyst for direct borohydride fuel cell. Int. J. Hydrogen Energy 2011, 36, 10319-10326. [CrossRef]

12. Milikić, J.; Stamenović, U.; Vodnik, V.; Ahrenkiel, S.P.; Šljukić, B. Gold nanorod-polyaniline composites: Synthesis and evaluation as anode electrocatalysts for direct borohydride fuel cells. Electrochim. Acta 2019, 328, 135115. [CrossRef]

13. Santos, D.M.F.; Šljukić, B.; Amaral, L.; Milikić, J.; Sequeira, C.A.C.; Macciò, D.; Saccone, A. Nickel-rare earth electrodes for sodium borohydride electrooxidation. Electrochim. Acta 2016, 190, 1050-1056. [CrossRef]

14. Šljukić, B.; Milikić, J.; Santos, D.M.F.; Sequeira, C.A.C. Carbon-supported $\mathrm{Pt}_{0.75} \mathrm{M}_{0.25}(\mathrm{M}=\mathrm{Ni}$ or Co) electrocatalysts for borohydride oxidation. Electrochim. Acta 2013, 107, 577-583. [CrossRef]

15. Hosseini, M.G.; Mahmoodi, R. Preparation method of Ni@Pt/C nanocatalyst affects the performance of direct borohydridehydrogen peroxide fuel cell: Improved power density and increased catalytic oxidation of borohydride. J. Colloid Interface Sci. 2017, 500, 264-275. [CrossRef] [PubMed]

16. Wei, J.; Wang, X.; Wang, Y.; Guo, J.; He, P.; Yang, S.; Li, N.; Pei, F.; Wang, Y. Carbon-supported Au hollow nanospheres as anode catalysts for direct borohydride-hydrogen peroxide fuel cells. Energy Fuels 2009, 23, 4037-4041. [CrossRef]

17. Deshmukh, K.; Santhanam, K.S.V. New borohydride fuel cell with multiwalled carbon nanotubes as anode: A step towards increasing the power output. J. Power Sources 2006, 159, 1084-1088. [CrossRef]

18. Hosseini, M.G.; Mahmoodi, R. Improvement of energy conversion efficiency and power generation in direct borohydridehydrogen peroxide fuel cell: The effect of $\mathrm{Ni}-\mathrm{M}$ core-shell nanoparticles $(\mathrm{M}=\mathrm{Pt}, \mathrm{Pd}, \mathrm{Ru}) /$ multiwalled carbon nanotubes on the cell performance. J. Power Sources 2017, 370, 87-97. [CrossRef]

19. Navarro-Flores, E.; Chong, Z.; Omanovic, S. Characterization of Ni, NiMo, NiW and NiFe electroactive coatings as electrocatalysts for hydrogen evolution in an acidic medium. J. Mol. Catal. A Chem. 2005, 226, 179-197. [CrossRef]

20. Zhou, W.; Wu, X.J.; Cao, X.; Huang, X.; Tan, C.; Tian, J.; Liu, H.; Wang, J.; Zhang, H. Ni $\mathrm{S}_{2}$ nanorods/Ni foam composite electrode with low overpotential for electrocatalytic oxygen evolution. Energy Environ. Sci. 2013, 6, 2921-2924. [CrossRef]

21. Martínez, R.; Romero, E.; Guimon, C.; Bilbao, R. $\mathrm{CO}_{2}$ reforming of methane over coprecipitated Ni-Al catalysts modified with lanthanum. Appl. Catal. A Gen. 2004, 274, 139-149. [CrossRef]

22. Tian, D.; Xu, Z.; Zhang, D.; Zhou, Y.; Sun, Z. Multifaceted roles of $\mathrm{FeCl}_{2}$ on pore formation of polyester fabric wastes-based activated carbon. Colloids Surf. A Physicochem. Eng. Asp. 2020, 598, 124756. [CrossRef]

23. Yuan, L.; Yan, Z.; Jiang, L.; Wang, E.; Wang, S.; Sun, G. Gold-iridium bifunctional electrocatalyst for oxygen reduction and oxygen evolution reactions. J. Energy Chem. 2016, 25, 805-810. [CrossRef]

24. Zdolšek, N.; Dimitrijević, A.; Bendová, M.; Krstić, J.; Rocha, R.P.; Figueiredo, J.L.; Bajuk-Bogdanović, D.; Trtić-Petrović, T.; Šljukić, B. Electrocatalytic activity of ionic-liquid-derived porous carbon materials for the oxygen reduction reaction. ChemElectroChem 2018, 5, 1037-1046. [CrossRef]

25. Claramunt, S.; Varea, A.; López-Díaz, D.; Velázquez, M.M.; Cornet, A.; Cirera, A. The importance of interbands on the interpretation of the Raman spectrum of graphene oxide. J. Phys. Chem. C 2015, 119, 10123-10129. [CrossRef]

26. Cherevko, S.; Zeradjanin, A.R.; Keeley, G.P.; Mayrhofer, K.J.J. A comparative study on gold and platinum dissolution in acidic and alkaline media. J. Electrochem. Soc. 2014, 161, H822-H830. [CrossRef]

27. Santos, D.M.F.; Šljukić, B.; Amaral, L.; Macciò, D.; Saccone, A.; Sequeira, C.A.C. Nickel and nickel-cerium alloy anodes for direct borohydride fuel cells. J. Electrochem. Soc. 2014, 161, 594-599. [CrossRef]

28. Spinner, N.; Mustain, W.E. Effect of nickel oxide synthesis conditions on its physical properties and electrocatalytic oxidation of methanol. Electrochim. Acta 2011, 56, 5656-5666. [CrossRef]

29. Faro, M.L.; Reis, R.M.; Saglietti, G.G.A.; Zignani, S.C.; Trocino, S.; Frontera, P.; Antonucci, P.L.; Ticianelli, E.A.; Aricò, A.S. Investigation of Ni-based alloy/CGO electro-catalysts as protective layer for a solid oxide fuel cell anode fed with ethanol. J. Appl. Electrochem. 2015, 45, 647-656. [CrossRef]

30. Oliveira, V.L.; Morais, C.; Servat, K.; Napporn, T.W.; Olivi, P.; Kokoh, K.B.; Tremiliosi-Filho, G. Kinetic investigations of glycerol oxidation reaction on $\mathrm{Ni} / \mathrm{C}$. Electrocatalysis 2015, 6, 447-454. [CrossRef]

31. Hosseini, M.G.; Abdolmaleki, M.; Ashrafpoor, S. Electrocatalytic oxidation of sodium borohydride on a nanoporous Ni/Zn-Ni electrode. Chin. J. Catal. 2012, 33, 1817-1824. [CrossRef]

32. Duan, D.; Liang, J.; Liu, H.; You, X.; Wei, H.; Wei, G.; Liu, S. The effective carbon supported core-shell structure of Ni@Au catalysts for electro-oxidation of borohydride. Int. J. Hydrogen Energy 2015, 40, 488-500. [CrossRef]

33. Olu, P.Y.; Bonnefont, A.; Rouhet, M.; Bozdech, S.; Job, N.; Chatenet, M.; Savinova, E. Insights into the potential dependence of the borohydride electrooxidation reaction mechanism on platinum nanoparticles supported on ordered carbon nanomaterials. Electrochim. Acta 2015, 179, 637-646. [CrossRef] 
34. Geng, X.; Zhang, H.; Ye, W.; Ma, Y.; Zhong, H. Ni-Pt/C as anode electrocatalyst for a direct borohydride fuel cell. J. Power Sources 2008, 185, 627-632. [CrossRef]

35. Oshchepkov, A.G.; Braesch, G.; Ould-Amara, S.; Rostamikia, G.; Maranzana, G.; Bonnefont, A.; Papaefthimiou, V.; Janik, M.J.; Chatenet, M.; Savinova, E.R. Nickel Metal Nanoparticles as Anode Electrocatalysts for Highly Efficient Direct Borohydride Fuel Cells. ACS Catal. 2019, 9, 8520-8528. [CrossRef]

36. Lee, S.-M.; Kim, J.-H.; Lee, H.-H.; Lee, P.S.; Lee, J.-Y. The characterization of an alkaline fuel cell that uses hydrogen storage alloys. J. Electrochem. Soc. 2002, 149, A603. [CrossRef]

37. Wang, K.; Juntao Lu, L.Z. A current-decomposition study of the borohydride oxidation reaction at Ni electrodes. J. Phys. Chem. C 2007, 111, 7456-7462. [CrossRef]

38. Pasqualeti, A.M.; Olu, P.Y.; Chatenet, M.; Lima, F.H.B. Borohydride electrooxidation on carbon-supported noble metal nanoparticles: Insights into hydrogen and hydroxyborane formation. ACS Catal. 2015, 5, 2778-2787. [CrossRef]

39. Chatenet, M.; Molina-Concha, M.B.; Diard, J.P. First insights into the borohydride oxidation reaction mechanism on gold by electrochemical impedance spectroscopy. Electrochim. Acta 2009, 54, 1687-1693. [CrossRef]

40. Hosseini, M.G.; Mahmoodi, R.; Sadeghi Amjadi, M. Carbon supported $\mathrm{Ni}_{1} \mathrm{Pt}_{1}$ nanocatalyst as superior electrocatalyst with increased power density in direct borohydride-hydrogen peroxide and investigation of cell impedance at different temperatures and discharging currents. Energy 2017, 131, 137-148. [CrossRef]

41. Oliveira, R.C.P.; Milikić, J.; Daş, E.; Yurtcan, A.B.; Santos, D.M.F.; Šljukić, B. Platinum/polypyrrole-carbon electrocatalysts for direct borohydride-peroxide fuel cells. Appl. Catal. B Environ. 2018, 238, 454-464. [CrossRef]

42. Simoes, M.; Baranton, S.; Coutanceau, C. Electrooxidation of sodium borohydride at Pd, $\mathrm{Au}$, and $\mathrm{Pd}_{\mathrm{x}} \mathrm{Au}_{1-\mathrm{x}}$ carbon-supported nanocatalysts. J. Phys. Chem. C 2009, 113, 13369-13376. [CrossRef]

43. Santos, D.M.F.; Sequeira, C.A.C. Cyclic voltammetry investigation of borohydride oxidation at a gold electrode. Electrochim. Acta 2010, 55, 6775-6781. [CrossRef]

44. Oliveira, R.C.P.; Sevim, M.; Šljukić, B.; Sequeira, C.A.C.; Metin, Ö.; Santos, D.M.F. Mesoporous graphitic carbon nitride-supported binary $\mathrm{MPt}(\mathrm{M}: \mathrm{Co}, \mathrm{Ni}, \mathrm{Cu}$ ) nanoalloys as electrocatalysts for borohydride oxidation and hydrogen evolution reaction. Catal. Today 2019, 357, 291-301. [CrossRef]

45. Dong, H.; Feng, R.; Ai, X.; Cao, Y.; Yang, H.; Cha, C. Electrooxidation mechanisms and discharge characteristics of borohydride on different catalytic metal surfaces. J. Phys. Chem. B 2005, 109, 10896-10901. [CrossRef] [PubMed]

46. Backović, G.; Milikić, J.; De Negri, S.; Saccone, A.; Šljukić, B.; Santos, D.M.F. Enhanced borohydride oxidation kinetics at gold-rare earth alloys. J. Alloys Compd. 2020, 857, 158273. [CrossRef]

47. Liu, X.; Yi, L.; Wang, X.; Su, J.; Song, Y.; Liu, J. Graphene supported platinum nanoparticles as anode electrocatalyst for direct borohydride fuel cell. Int. J. Hydrogen Energy 2012, 37, 17984-17991. [CrossRef]

48. Liu, J.; Wang, H.; Wu, C.; Zhao, Q.; Wang, X.; Yi, L. Preparation and characterization of nanoporous carbon-supported platinum as anode electrocatalyst for direct borohydride fuel cell. Int. J. Hydrogen Energy 2014, 39, 6729-6736. [CrossRef]

49. Sombatmankhong, K. Improved performance and stability of direct borohydride fuel cells (DBFCs) with porous polypyrrole support. J. Porous Mater. 2015, 22, 675-687. [CrossRef]

50. He, P.; Wang, X.; Fu, P.; Wang, H.; Yi, L. The studies of performance of the Au electrode modified by Zn as the anode electrocatalyst of direct borohydride fuel cell. Int. J. Hydrogen Energy 2011, 36, 8857-8863. [CrossRef]

51. Geng, X.; Zhang, H.; Ma, Y.; Zhong, H. Borohydride electrochemical oxidation on carbon-supported Pt-modified Au nanoparticles. J. Power Sources 2010, 195, 1583-1588. [CrossRef] 